\title{
Pneumatosis Cystoides-like Histopathologic Appearance in a Mature Ovarian Teratoma
}

\section{Olgun Bir Yumurtalık Teratomunda Pneumatosis Cystoides Benzeri Histopatolojik Görünüm}

Michail LITOS ${ }^{\circledR}$, Dimitra T. VASILEIADOU®, Christos IAVAZZO๑, Michael LENOS ${ }^{\circledR}$, Konstantia BAKALIANOU®

Ethics Committee Approval: Not Applicable.

Conflict of Interest: The authors declare that they have no conflict of interest.

Funding: None.

Informed Consent: Informed consent was taken.
Cite as: Litos M, Vasileiadou DT, lavazzo C, Lenos M, Bakalianou K. Pneumatosis cystoides-like histopathologic appearance in a mature ovarian teratoma. Medeni Med J. 2021;36:163-6.

\begin{abstract}
Pneumatosis cystoides-like pattern is a group of histopathological features occasionally found in ovarian teratomas. This is a case of laparoscopic ovarian cystectomy performed for incomplete adnexal torsion where histology reported mature ovarian teratoma with "pneumatosis cystoideslike appearance". This term is used to describe the presence of multiple cystic spaces within the tumor wall. It has been reported also in other organs, such as gastrointestinal tract, urinary bladder and the vagina. It may be secondary to mechanical, bacterial or ischemic causes, with the pathogenesis remaining unclear. It is benign and may exist more often than reported.
\end{abstract}

Keywords: Teratoma, ovary, pneumatosis cystoides

öz

Pneumatosis cystoides benzeri örüntü, yumurtalık teratomlarında bazen görülen bir grup histopatolojik özelliktir. Bu, histolojinin "pneumatosis cystoides benzeri görünüm" ile olgun over teratomu olarak rapor ettiği, inkomplet adneksiyal torsiyon için uygulanmış laparoskopik over kistektomisi vakasıdır. Bu terim, tümör duvarı içinde çoklu kistik boşlukların varlığını tanımlamak için kullanılır. Gastrointestinal sistem, idrar kesesi ve vajina gibi diğer organlarda da bildirilmiştir. Patogenezi belirsizken mekanik, bakteriyel veya iskemik nedenlere ikincil olabilir. lyi huyludur ve bildirilenden daha sık görülebilir.

Anahtar kelimeler: Teratom, over, pneumatosis cystoides
Received: 24 January 2021

Accepted: 14 May 2021

Online First: 18 June 2021

Corresponding Author: D.T. Vasileiadou ORCID: 0000-0003-1338-0914 Konstantopouleio General Hospital of Nea Ionia, Department of Obstetrics \& Gynecology, Athens, Greece

dimitra.vas@hotmail.com

\section{Litos}

ORCID: 0000-0001-6708-4681

K. Bakalianou

ORCID: 0000-0001-8034-9314 Konstantopouleio General Hospital of Nea Ionia, Department of Obstetrics \& Gynecology, Athens, Greece

C. Iavazzo

ORCID: 0000-0003-2119-4599 Metaxa Anticancer Hospital, Department of Gynecologic Oncology, Piraeus, Greece

M. Lenos ORCID: 0000-0003-3174-0194 Konstantopouleio General Hospital of Nea Ionia, Department of Pathology,

Athens, Greece 


\section{INTRODUCTION}

Ovarian teratomas are common ovarian lesions ${ }^{1}$. Most gynecologic surgeons are familiar with the diagnosis and management of teratomas, but less so with their pathology. A histopathologic finding that may raise queries to the clinician is pneumatosis cystoides-like appearance. Although rarely reported, it is not uncommon in mature cystic ovarian teratomas. The aim of this study is to report a case of pneumatosis cystoides found in an ovarian teratoma and to familiarize clinicians with this underreported entity.

\section{CASE REPORT}

A 35-year-old nulligravida presented with unilateral pelvic pain gradually worsening over two weeks, suggestive of incomplete adnexal torsion. Ultrasound examination revealed a cystic mass on the right ovary $(70.2 \times 44.4 \mathrm{~mm})$ with echogenic component and a marked acoustic shadow ("tip of the iceberg" sign). She underwent diagnostic laparoscopy and laparoscopic ovarian cystectomy with an uneventful intraoperative and postoperative course.

The histologic diagnosis was mature cystic ovarian teratoma with a pneumatosis-like pattern. The lesion consisted of various-sized cystic areas with fibrous septae. The walls of cystic areas were lined with foamy, rather widened, CD68 positive (+) histiocytes and multinucleated giant cells. Luminal-like formations were identified within the fibrous septae, some of which had an endothelial lining (CD34 positive (+), FVIII focally positive $(+)$, WT1 focally positive $(+)$, negative $(-)$ mesothelial indices), as well as nidi of lipophagocytes with a vacuolated cytoplasm and eccentric nuclei (CD68 positive $(+)$, negative (-) epithelial indices). Displaced ovarian stroma was identified on the verges of the tissue block, containing primordial and primary follicles. Sections from the cystic portion of the neoplasm demonstrated structures of fibrous wall, lined partially with widened squamous epithelium and the foreign body type local phagocytic granular reaction (Figures 1-2).

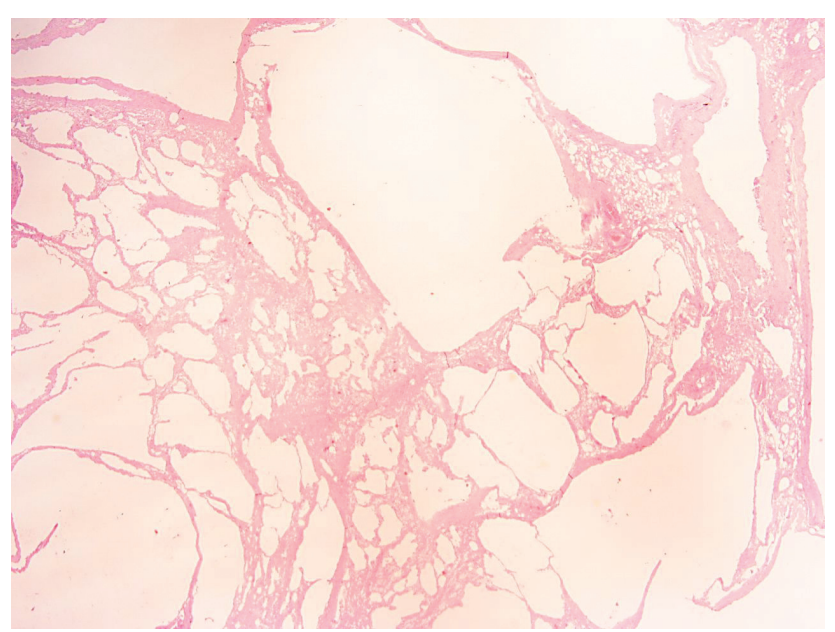

Figure 1. Teratoma, pneumatosis cystoides-like appearance, H\&E, 20x.

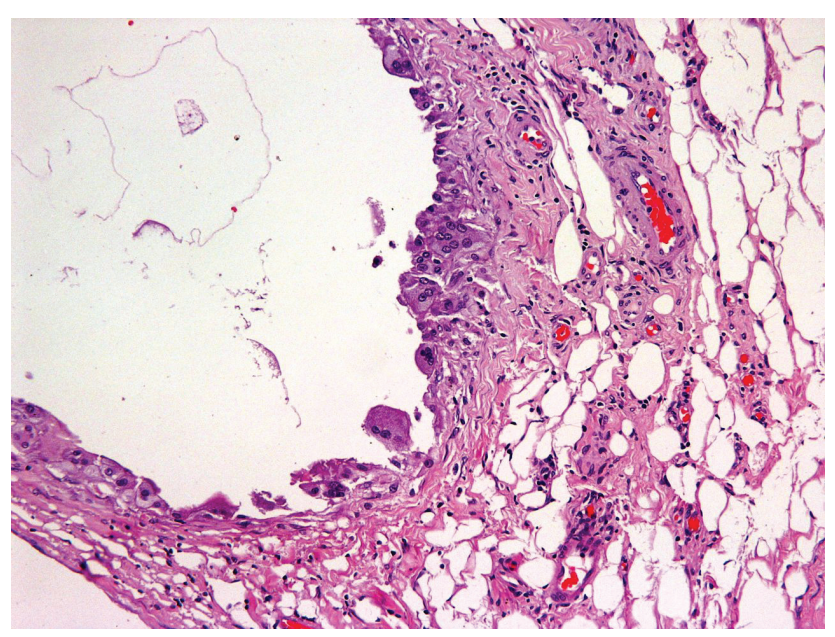

Figure 2. Teratoma, pneumatosis cystoides-like appearance, H\&E, 200x.

\section{DISCUSSION}

Teratomas belong to the germ cell family of ovarian neoplasms. They arise from a single germ cell, and therefore may contain any of the three germ layers (endoderm, mesoderm or ectoderm) and these layers are typically disorganized. Teratomas are classified as mature (benign), immature (malignant), and mono-dermal. Benign teratomas are most often cystic and composed of mature cells (mature cystic teratoma or dermoid 
cyst), while malignant teratomas contain immature cells and are usually solid with a cystic component. Mono-dermal teratomas are benign and composed solely or predominantly of one highly specialized tissue type (for instance, struma ovarii which is composed dominantly of thyroid tissue) $)^{2}$.

Among teratoma types, mature cystic teratoma is by far the most common, accounting for $10-25 \%$ of all ovarian neoplasms. The cysts are slow growing, usually unilocular (90\%) with a smooth wall and typically contain ore area of localized growth when opened (Rokitansky protuberance). While endodermal or mesodermal derivatives may be found, ectodermal elements are usually predominant. Thick sebaceous fluid, masses of hair and firm areas of cartilage, and teeth are often found within the cyst ${ }^{2}$.

Pneumatosis cystoides-like pattern encompasses pathologic features of foreign-type reaction or of lipophagic granulomatous reaction and it may include cystic spaces with pseudovascular, spongiform or sieve-like appearances ${ }^{3}$. This pattern was described in various other organs, such as the gastrointestinal tract (pneumatosis cystoides intestinalis) ${ }^{4}$, the urinary bladder (emphysematous cystitis) $^{5}$, or the vagina (emphysematous vaginitis) $^{6}$. There were also reports on ovarian $^{7}$ and endometrial ${ }^{8}$ pneumatosis.

When pneumatosis cystoides-like appearance occurs in an ovarian tumor, it is characteristic of mature cystic teratoma and may be considered as diagnostic, even when squamous epithelium is absent ${ }^{9}$. It is not a rare finding, although it is underreported, with less than 30 cases in the literature $^{10}$.

Regarding the pathogenesis of pneumatosis cystoides morphology, several pathophysiologic mechanisms have been proposed. Pneumatosis cystoides intestinalis was attributed to either mechanical or bacterial causes, namely inflammation, physical disruption of intestinal mucosa, nutritional imbalance, impaired intestinal microbiota, impaired gastrointestinal motility, and immunologic disturbance ${ }^{4}$. Gas-producing bacteria were implicated in emphysematous cystitis and vaginitis, in immunosuppressive conditions or in pregnancy. Microorganisms that are implicated in the pathogenesis of emphysematous cystitis are Escherichia coli (the most common), Enterobacter aerogenes, Klebsiella pneumoniae, Proteus mirabilis, Staphylococcus aureus, Streptococci, Clostridium perfringens, and Candida albicans ${ }^{5}$. Our patient had no evidence of infection or immunosuppression.

Another hypothesis suggests the deposition of oleous or sebaceous material that escaped from the cyst into the cystic wall or the small vessels, inducing a giant cell granulomatous response ${ }^{11}$. Increased intratumoral pressure may cause a focal disruption of the epithelial barrier, allowing oleous content to escape. This material may then implant as droplets within the fibrous tissue or remain in small vessels in the hilum of the ovary and induce granulomatous response of foreign body type, as macrophages surround lipid droplets and line vessels. Additional lipid material may be released from degenerated sebaceous glands and cause further phagocytic infiltration. Eventually, the oleous material is cleared by macrophages, leaving a rather acellular, sieve-like structure with no lining of either endothelium or macrophages ${ }^{\text {. }}$ This foreign body type response was indeed identified in our case.

Ischemia is another factor implicated in the pathogenesis of pneumatosis cystoides. It was hypothesized that disruption of the mucosal barrier allows invasion of the cystic wall with microbes and gas ${ }^{12}$. No such association has been reported regarding ovarian teratomas. However, it is plausible that incomplete adnexal torsion could cause a disruption of the endothelial barrier of the cystic wall with occasional impairment of 
blood supply contributing to the formation of pneumatosis cystoides morphology as in our case. Gastrointestinal endoscopy was suggestive of intestinal pneumatosis cystoides ${ }^{12}$ but current evidence does not support any association of this finding with the pneumoperitomeum during laparoscopic excision of the cyst.

\section{CONCLUSION}

Pneumatosis cystoides-like appearance is the histopathologic finding, that can be occasionally diagnosed in mature ovarian teratomas. The current study helps clinicians to become familiar with the term and remind tham that it is not an uncommon entity with benign characteristic features. However several mechanisms related to its pathogenesis remain unclear.

\section{REFERENCES}

1. Clement PB, Young RH. Germ cell tumors of the ovary. In: Clement PB, Young RH, editors. Atlas of Gynecologic Surgical Pathology. $3^{\text {rd }}$ ed. Elsevier; 2014.

2. Dolan MS, Hill C, Valea FA. Benign gynecologic lesions. In: Lobo RA, Gershenson DM, Lentz GM, Valea FA, editors. Comprehensive Gynecology. $7^{\text {th }}$ ed. Elsevier; 2017.
3. Al-Nafussi A. Tumors of the ovary. In: Al-Nafussi A, editor. Tumor Diagnosis: Practical approach and pattern analysis. $2^{\text {nd }}$ ed. Taylor \& Francis; 2005.

4. Wang YJ, Wang YM, Zheng YM, Jiang HQ, Zhang J. Pneumatosis cystoides intestinalis: six case reports and a review of the literature. BMC Gastroenterol. 2018;18:100. [CrossRef]

5. Amano M, Shimizu T. Emphysematous cystitis: a review of the literature. Intern Med. 2014;53:79-82. [CrossRef]

6. Lima-Silva J, Vieira-Baptista P, Cavaco-Gomes J, Maia T, Beires J. Emphysematous vaginitis. J Low Genit Tract Dis. 2015;19:e43-4. [CrossRef]

7. Wang Y, Topran EA, Tavassoli F. Pneumatosis ovarii (emphysematous changes in the ovary): a case report. Int J Gynecol Pathol. 2008;27:531-3. [CrossRef]

8. Chua YJ, Meharry S, Harding S, Stewart CJ. Endometrial pneumatosis (emphysematous endometritis). Int J Gynecol Pathol. 2014;33:511-4. [CrossRef]

9. Rubin A, Papadaki L. Multicystic structures appearing in mature cystic teratomas of the ovary: an immunohistochemical and ultrastructural study. Histopathology. 1990;17:359-63. [CrossRef]

10. Mathew M, Goel G, Susmitha, Kumar P. Mature cystic teratoma of the ovary with pneumatosis cystoides - like appearance. The Internet Journal of Pathology. 2008;8:1-3. Available from: https://print.ispub.com/api/0/ispubarticle/3986

11. Cierna Z, Danihel L. Mature ovarian teratoma with pneumatosis cystoides-like appearance-morphological and immunohistochemical study. Newslab. 2018;9:5-7. Available from: https://www.newslab.sk/en/zrelyovarialny-teratom-s-obrazom-podobnym-cystoidnejpneumatoze-morfologicka-a-imunohistochemicka-studia/

12. St Peter SD, Abbas MA, Kelly KA. The spectrum of pneumatosis intestinalis. Arch Surg. 2003;138:68-75. [CrossRef] 